\title{
Hogyan lehet támogatni a (nyelv)tanulást a fejlesztő értékelésen keresztül?
}

\author{
Csépes Ildikó ${ }^{1}$
}

Debreceni Egyetem

DOI: 10.14232/edulingua.2020.1.5

\begin{abstract}
Tanulmányunk célja, hogy áttekintést adjon a fejlesztő értékelés különböző értelmezéseiről, a nyelvtanulás kontextusát külön is kiemelve. Bemutatjuk az osztálytermi értékelés megítélésének változását az elmúlt közel 30 év alatt, és hogy a fejlesztő értékelés miért kapott egyre több figyelmet napjainkra. Értelmezésünk szerint az értékelés átszövi az osztálytermi gyakorlat egészét, és jelentősen befolyásolhatja a diákok tanulási motivációját és magabiztosságát, melyek egyaránt döntő hatással lehetnek a tanulás eredményességére. Bemutatjuk a fejlesztő értékelés három megközelítését: a tanulást támogató értékelést, a dinamikus értékelést és a tanulás-orientált értékelés. Mindhárom felfogás rendelkezik sajátos jegyekkel, de abban egységesek, hogy az értékelést a tanítás szerves részének tekintik. Végül rövid kitekintést adunk a fejlesztő értékelést vizsgáló magyarországi kutatások eredményeit illetően. A közoktatás keretében zajló angolórák osztálytermi értékelési gyakorlatáról kibontakozó kép egyértelmüen alátámasztja a szemléletváltás szükségességét.
\end{abstract}

Kulcsszavak: osztálytermi értékelés, fejlesztő értékelés, tanulást támogató értékelés, differenciált értékelés, értékelési műveltség

\section{Bevezető}

A 21. század derekán tanúi lehettünk egy olyan pedagógiai szemléletváltás iránti igénynek, mely előtérbe helyezi a tanulóközpontú oktatást. A tanítás ennek megfelelően differenciálásra épül, és minden eszköztárával azt támogatja, hogy a tanuló önszabályozóvá váljon és képes legyen magáért felelősséget vállalni, ezáltal is megalapozva az élethosszig tartó tanulás esélyét. Ezeket a célokat tüzte ki az OECD Oktatáspolitikai Bizottsága „A jövő oktatása és készségei 2030” (Future of Education and Skills 2030) projekt elindításával 2015-ben, melyhez kapcsolódóan már elérhetőek tantervi és útmutató füzetek Magyarországon (Lásd Katona és mtsai, 2020). A pedagógiai kultúraváltás szükségességét Magyarországon azonban nemcsak a korszellem, hanem az idegennyelv-tanulás viszonylagos sikertelensége is indokolja (Einhorn, 2015). A 2012-ben felvett Eurobarometer adatok (Europeans and their Languages, 2012: 15) szerint Magyarországon, az Európai Unióban abszolút

\footnotetext{
${ }^{1}$ e-mail: csepes.ildiko@arts.unideb.hu
} 
sereghajtóként, a megkérdezetteknek mindössze 35\%-a állította magáról, hogy legalább egy idegen nyelven beszél. Ez az adat az előző felmérés eredményéhez viszonyítva még rosszabb képet fest rólunk, mivel 2006-ban a megkérdezettek 42\%-a állította ugyanezt (Europeans and their Languages, 2006: 9). A meglehetősen kedvezőtlen tendencia megállításához intervencióra van szükség. Feltételezésünk szerint a tanárok jelentős mértékben hozzá tudnának járulni ahhoz, hogy a problémát orvosolni lehessen. Ehhez elengedhetetlen azonban, hogy kritikusan megvizsgálják saját osztálytermi értékelési gyakorlatukat és készek legyenek a szükséges változtatásokat végrehajtani.

Einhorn véleménye szerint a magyar közoktatás pedagógiai kultúrája viszonylag konzervatívnak tekinthetö, hiszen a tanítási órákat tanárközpontú, ismeretalapú megközelítés jellemzi. Az osztálytermi értékelés alapjában véve „,beskatulyáz és megbélyegez" (2015: 54), és ezért a tanuló vesztesnek vagy nyertesnek érezheti magát. $\mathrm{Az}$ értékelés legfőbb alapja tehát a másokkal történő összehasonlítás (normaorientált értékelés) és célja a minősítés (szummatív értékelés) ahelyett, hogy az értékelés a tanuló egyéni fejlődését célzottan támogatná. Az osztálytermi értékelés területén tehát indokoltnak tünik a szemléletváltás. Ennek eredményeképpen egyrészt csökkenne az értékeléssel szembeni negatív hozzáállás, másrészt az értékelés változatos formáit a tanulás eredményességének szolgálatába lehetne állítani. Az osztálytermi mérés és értékelés ez utóbbi felfogását Black és Wiliam (1998) 'a tanulást támogató értékelésnek' nevezi (assessment for learning). A differenciált értékelés a pedagógiai kultúraváltáshoz azért elengedhetetlen, mert az eredményes (nyelv)tanulás katalizátora lehet.

Tanulmányunkban rövid áttekintést nyújtunk az osztálytermi értékelés föbb céljairól (diagnosztikus, minősítő és fejlesztő), melyek közül a fejlesztő értékelés fogalmát részletesebben is tárgyaljuk. Bemutatjuk, hogy az osztálytermi értékelés megítélése általában és célzottan a nyelvtanulásra vonatkozóan hogyan változott az elmúlt közel 30 év alatt, és hogy a fejlesztő értékelés miért kapott egyre több figyelmet napjainkra. Áttekintésünk során az osztálytermi értékelés néhány értelmezését külön is megvilágítunk, mivel mindegyiket fontosnak ítéljük a fogalom fejlődése szempontjából. Ezek közé tartozik a tanulást támogató értékelés (assessment for learning), a dinamikus értékelés (dynamic assessment/DA) és a tanulás-orientált értékelés (learning-oriented assessment/LOA).

\section{Az osztálytermi értékelés céljai}

Az osztálytermi értékelésnek három főbb célját különböztetik meg. Az egyik a helyzetfeltáró (diagnosztikus) értékelés, mely a teszt típusok egyik jól ismert fajtája (Green, 2014). A másik két típus megnevezését oktatási programok értékelésére vonatkozóan elöször Scriven (1967) használta, aki megkülönböztette a tanulási folyamatot fejlesztő (formatív) és minősítő (szummatív) értékelést. A három eltérő céllal kivitelezett értékelési formát Brassói és mtsai (2005), valamint Bognár (2006) 
meglátásai alapján definiáljuk. A helyzetfeltáró értékelés célja, hogy a tanár a diákok szükségleteihez illeszkedő tanmenetet tudjon kialakítani azáltal, hogy feltárja a tanulók előismereteit és hiányosságait, melyeket igyekszik pótolni a pedagógiai folyamatok tervezésekor. A minősítő értékelés során a tanár megítéli a tanulói teljesítményeket, rangsorolja a tanulókat meghatározott standard vagy követelmény alapján. A fejlesztő értékelés pedig arra irányul, hogy ,a diák eredményesebb tanulását segítse, ne ítélje meg (különösen ne ítélje el) az [addigi] munkát, hanem mutasson rá azokra a lehetőségekre, amelyekkel a tanulási folyamat eredményesebbé válhat" (Brassói és mtsai, 2005: 4). A fejlesztő értékelés tehát a tanulási folyamatot támogatja, formálja. Mivel a tanulók egyéni szükségletei eltérhetnek, a fejlesztő értékelés kiegészülhet differenciált tanítási/tanulási módszerek megjelenésével is.

Bognár (2006) szerint a fejlesztő értékelésnek három lényeges jellemzője van: (i) a tevékenység gyakorta elöfordul, (ii) a folyamat interaktív, azaz a diák is aktívan részt vesz benne, (iii) a diák fogalmazza meg a tanulási célokat, de a későbbi értékelési tapasztalatok alapján szükség szerint módosítja őket, hogy elösegítse a folyamatos fejlődést. Bognár szerint ez a három jellemző különbözteti meg a fejlesztő értékelést a diagnosztikus értékeléstől.

Brassói és mtsai (2005: 9) a fejlesztő értékelést támogató keretrendszert is felvázolják, mely a következő szempontokra terjed ki:

- Olyan osztálytermi légkört kell kialakítani, amelyben a diákok biztonságban érzik magukat, amely a diákok számára nem versenyhelyzetet teremt, hanem a feladatmegoldásra és az érzelmi-akarati tényezőkre helyezi a hangsúlyt.

- A tanulási célokat egyértelműen kell meghatározni, és az egyéni tanulói fejlődés lépéseit monitorozni kell, mert ezek segítségével fokozható a tanulói motiváció. Versenyhelyzetben a tanulók egymáshoz hasonlítják az elért eredményeiket, és emiatt a gyengébb tanuló elvesztheti meglévő motivációját és önbizalmát is.

- A különböző tanulási igényü tanulók szükségletei eltérhetnek, ezért kívánatos, hogy a tanár sokféle tanítási módszert alkalmazzon.

- A tanulók elörehaladását, teljesítményét változatosan kell értékelni. Ez megvalósulhat akár minősítő értékelési formák újszerü felhasználásával, de olyan alternatív értékelési formák alkalmazása is javasolt, mint a portfólió, önértékelés vagy társértékelés.

- A tanulói teljesítményre, előrehaladásra reflektáló tanári visszacsatolást lehetőség szerint gyakran kell alkalmazni.

- Fontos, hogy a tanulók aktívan vegyenek részt a tanulási folyamatban. 
Bognár (2006) véleménye szerint nem egyszerü áttérni a fejlesztő értékelésre olyan iskolai környezetben, ahol a hagyományos szemléletet tükröző minősítő értékelés dominál. Az osztálytermi értékelés gyakorlatának megváltoztatásához szükséges szemléletváltást részben a tanárok számára elérhető képzések biztosíthatják a fejlesztő értékelés módszereinek és eljárásainak bemutatásával, részben pedig az, hogy az egész nevelőtestület elfogadja-e, elköteleződik-e mellette, hiszen teljes körü elfogadottság és támogatás esetén a sikeres gyakorlati megvalósítás esélye is megnő.

A minősítő és a fejlesztő értékelés közötti határvonal azonban nem olyan egyértelmü. Rea-Dickins és Gardner (2000) szerint a határvonal elmosódása leginkább abban érhető tetten, hogy a fejlesztő értékelésnek is lehet adott esetben olyan súlya és következménye, mint egy minősítő értékelésnek. Például akkor, ha a tanári visszajelzés összességében alul- vagy felülértékeli a diák teljesítményét, vagy a diák nem megfelelő feladatok alapján kapja a visszacsatolást, netán a kapott információkat tévesen értelmezi. Ezek a példák mind arra világítanak rá, hogy a fejlesztő értékelés megvalósítása számos csapdát rejt, még ha célját tekintve oly vonzónak is tűnik. Bennett (2011) viszont azt emeli ki, hogy a minősítő értékelés másodlagos célja eleve a fejlesztés, hiszen a minősítő teszt is tanulási lehetőséget nyújt a tanuló számára.

Golnhofer 2001-ben egy nemzetközi viszonylatban akkor még újnak nevezhető értékelési kultúra megjelenéséről adott számot, mely képes a nevelés és az oktatás eredményességének, minőségének, illetve hatékonyságának növelésére. A fejlesztő értékelés fentebb vázolt ismérveivel sok tekintetben összecseng a Golnhofer által vázolt értékelési kultúra néhány jellemzője, mint például az, hogy megnő az értékeléssel kapcsolatos tudatosság és stratégiahasználat, kibővül az értékelök köre, és felerősödik a felelősségvállalás igénye. Jóllehet a fejlesztő értékelés a múlt században is létező eszköz volt a tanár kezében, nem álltak rendelkezésre a fejlesztő értékelést a minősítő értékeléssel összevető szakmai ajánlások. Az elmúlt két évtizedben ezt a hiányosságot sikerült jórészt pótolni, bár a mai napig nincs egységes és átfogó definíció a fogalom értelmezéséhez. Bennett (2011) rámutat például arra, hogy a fejlesztő értékelést egyesek eszközként, mások folyamatként definiálják, holott szerinte a kettő elválaszthatatlan egymástól, hiszen kiegészítik egymást. A fogalom megszületésekor is ilyen elképzelés társult hozzá Lau (2016) szerint, aki hasonló véleményt képvisel azzal kiegészítve, hogy a fejlesztő értékelés manapság sokak számára a 'jó' értékelés, míg a minősítő értékelésre a 'rossz' értékelés címkét ragasztották. Ez a megítélés tükröződik abban is, hogy a tanároknak illendő az utóbbit minimalizálni és az elöbbit pedig előtérbe helyezni. Lau kiemeli, hogy eredetileg a két értékelési típus egyensúlyban volt, de a 2000-es évekre a minősítő értékelés domináns lett a külső vizsgák egyre nagyobb térnyerésével, elsősorban az összevethetőség az elszámoltathatóság fokozódó nyomása miatt. Azonban a külső vizsgák megnövekedett társadalmi szerepével párhuzamosan a fejlesztő értékelés is egyre inkább kiemelt figyelmet nyert, elsősorban az oktatáskutatók oldaláról. 
Az 1990-es években több elnevezés is napvilágot látott, melyek a minősítő értékelést hagyományosnak (eredmény-centrikusnak és normaalapúnak), a fejlesztő értékelést pedig - akkor még - új, alternatív értékelésnek állították be (Lau, 2016). Birenbaum (1996) az előbbit például tesztelési kultúrának (testing culture), az utóbbit értékelési kultúrának (assessment culture) nevezi. A létrejött szembeállítás (dichotómia) azt sugalmazza, hogy a kettő közül választani kell, melynek eredményeképpen a fejlesztö értékelés szerepének a vizsgálata egyre több figyelmet kapott a 2000-es évek elejére (Assessment Reform Group, 2002; Stiggins, 2002, 2007). Inbar-Lourie (2008) azonban a minősítő és a fejlesztő értékelés szembeállítása helyett a kettő egymást kiegészítő jellegét hangsúlyozza, és az értékelési kultúra fogalmát egy tágabb elméleti és gyakorlati keretben értelmezi, amely a tudástranszfer konstruktivista szemléletü felfogásán alapszik. Ennek megfelelően az értékelés alapját több mikro- és makroszintü adatforrás biztosítja, és az értékelés folyamatában minden érintett fél aktívan részt vesz. Az értékelés területén is szükséges a tanuló készségfejlesztése, mely az egész életen át tartó tanulását támogathatja. Inbar-Lourie arra is rámutat, hogy az eredetileg Gipps (1994) nevéhez köthető fogalom, a tanulás eredmény-orientált értékelése (assessment of learning), a behaviorista tudástranszfer szemléletet jeleníti meg, mely a hierarchikusan egymásra épülő kisebb, izolált tudáselemek átadását jelenti. A tanulás eredményorientált értékelése szerint a tudást egységesen, standardizált tesztek segítségével mérik annak érdekében, hogy rangsorolni vagy kiszürni lehessen a tanulókat. Harlen (2005) hasonlóan ítéli meg a tanulás eredmény-orientált értékelésére vonatkozó tudástranszfer szemléletet, hozzátéve, hogy ez a fajta értékelés sokszor káros teszthatást generál (leszükítheti a tananyagot), mivel a tanárok a tanítás során a külső tesztek tartalmára koncentrálnak, valamint a tesztre való felkészítést gyakori próbateszteléssel és a tesztben alkalmazott kérdéstípusok begyakoroltatásával érik el. A negatív hatás adott esetben még úgy is értelmezhető, hogy bár a tanulók a kiválasztott teszten jó eredményt érnek el, összességében a megszerzett tudásuk alkalmazhatósága limitált. A tanulók motivációját is kedvezőtlenül befolyásolhatja a gyakori osztálytermi tesztelés, mivel az elért alacsony eredmények növelhetik szorongásukat és csökkenthetik az önmagukba vetett hitet. A fenti jellemzők alapján a tanárok osztálytermi gyakorlatát lehet tesztorientáltnak vagy tanulás-orientáltnak nevezni (Harlen, 2005), az utóbbi esetben a fejlesztő értékelésnek értelemszerüen nagyobb szerep jut. Összességében megállapíthatjuk, hogy a külső vizsgákat, osztálytermi tesztelést előtérbe helyező oktatási közegben a tanuló egyénre szabott, képességeihez és igényeihez illeszkedő, fejlesztő jellegü támogatására kevés esély van, hiszen a tanár figyelmét lekötik az adott külső teszthez kapcsolódó tevékenységek. A minősítő és fejlesztő értékelés közötti kapcsolat normalizálását Harlen (2005) abban látja, ha a két alapvető értékelési cél (minősítés és fejlesztés) fenntartása mellett, az értékelési formák és eljárások átjárhatóvá válnak: a fejlesztő értékelés szolgáljon alapul a minősítő értékeléshez és fordítva. 


\section{A tanulást támogató értékelés}

Az elmúlt közel három évtized alatt egy sor új fogalom jelent meg a szakirodalomban, melyek végső soron ugyanazt a célt szolgálják: a tanuló (nyelv)tanulásának támogatását, tudásának fejlesztését. Az értékelés minősítő, a tanulás eredményességét ellenőrző szerepével szemben a fejlesztő értékelést többen is újraértelmezték, köztük Black és Wiliam (1998), valamint Stiggins (2002). A tanulást támogató értékelés (assessment for learning) mint fogalom megjelenése elsősorban Black és Wiliam (1998) metaanalízisének köszönhető, melyet az Assessment Reform Group (Értékelési Reform Csoport) felkérésére készítettek. Black és Wiliam 250 empirikus tanulmány eredményét tekintette át, mely azt mutatta, hogy ha a fejlesztő értékelés bizonyos elvek és eszközök alkalmazására épül, az pozitívan hat a tanulók eredményességére, különösen az alacsony szinten, azaz gyengén teljesítő tanulók esetében. A tanulmány címe, „A fekete dobozon belül" (Inside the Black Box) is sokat sejtetően hangzik, mivel egy igen nehezen vizsgálható, szinte kifürkészhetetlen terület feltárását célozza meg: hogyan lehet a tanulást támogatni, a tanuló fejlődését elősegíteni osztálytermi közegben. Taras (2009) szerint Black és Wiliam munkásságának jelentősége abban is megmutatkozik, hogy két olyan metafora, új fogalom megalkotása füzödik hozzájuk - a fekete dobozon belül (inside the black box) és a tanulást támogató értékelés (assessment for learning) melyek lángra gyújtották számos kutató és oktatási szakember képzeletét az oktatáspolitika átalakításától az osztálytermi értékelési gyakorlat megváltoztatásáig.

Black és Wiliam (1998) tanulmányukban a konstruktív visszacsatolást jelölik meg mint kulcsfontosságú tényezőt, mely képes pozitívan befolyásolni a tanulói eredményességet. Megállapították, hogy a tanuló munkájával kapcsolatos visszacsatolás nem lehet csak leíró jellegü, hanem a továbblépés érdekében útbaigazítást is kell adnia a tanuló számára, továbbá kerülni kell a többi tanulóval való összehasonlítást. Sadler (1998) is fontosnak ítéli a visszajelzés szerepét, melynek minőségét az emelheti, ha az a tanuló számára könnyen értelmezhető, az előrehaladást hatékonyan képes támogatni, illetve a tanuló magabiztosságát és képességeibe vetett hitét erősíti.

Black és Wiliam (1998) kiemelik, hogy számos sikeres oktatási kísérlet alkalmazott tanulói ön- és társértékelést a fejlesztő értékelés támogató eszközeként, és az eredmények alapján levont következtetésük az volt, hogy a fejlesztő értékelés és az önértékelés szorosan összetartozik, az önértékelés az előbbinek szerves része. Black és Wiliam értelmezése szerint:

(...) a tanuló önértékelése messze nem luxuscikk, valójában a fejlesztő értékelés alapvető eleme. Amikor bárki azzal próbálkozik, hogy valamit megtanuljon, az erőfeszítéseire vonatkozó visszacsatolásnak három elemet kell tartalmazni: a tanuló legyen képes beazonosítani a számára kitüzött tanulási célt; szolgáljon bizonyítékkal a tanuló számára jelenlegi pozíciója és eredményessége megértéséhez; értse meg a tanuló, hogy a tanulási célja és a jelenlegi pozíciója közötti szakadék hogyan hidalható át. Ahhoz, hogy a 
tanuló elöbbre tudjon lépni, mindhárom elemmel tisztában kell, hogy legyen. (1998: 143; Ford. a szerzö)

A visszacsatoláson és tanulói önértékelésen túl Black és Wiliam (1998) megállapítása szerint a tanári kérdezéstechnikák is jelentősen befolyásolhatják a tanulói eredményességet. A tanulók és a tanár között létrejövő órai párbeszéd azt a célt kell, hogy szolgálja, hogy minden tanuló elgondolkozzon és véleményt mondhasson. A tanár által feltett kérdéseknek ezért átgondoltnak, reflektívnek, és célzottnak kell lenniük.

A Black és Wiliam (1998) által szintetizált kutatási eredményeket az Értékelési Reform Csoport gyakorlati útmutató formájába öntötte, melyben a tanulás eredményorientált értékelését és a tanulást támogató értékelést egyértelmüen elkülönítik, az utóbbi megvalósítását öt kulcstényezőhöz kötik (Broadfoot és mtsai, 1999: 4-5):

- hatékony visszacsatolás biztosítása a tanulók számára;

- a tanulók aktív bevonása saját tanulásukba;

- a tanmenet és/vagy az alkalmazott tanítási módszerek módosítása az értékelés eredménye alapján;

- annak felismerése, hogy az értékelés jelentősen befolyásolhatja a tanulók motivációját és önértékelését, melyek egyaránt döntő hatással lehetnek a tanulás eredményességére;

- annak az igénynek elismerése, hogy a tanulóknak képeseknek kell lenniük az önértékelésre, és meg tudják érteni, mi szükséges saját fejlődésükhöz.

Broadfoot és mtsai szerint a tanulást támogató értékelés során a tanulók tudatosítják a tanulási célokat és az elérni kívánt normákat, és az értékelést megosztva, a tanárral együttmüködve végzik. Összességében az értékelésnek azt az üzenetet kell közvetítenie, hogy minden tanuló képes a fejlődésre.

A tanulást támogató értékelést azonban számos tényező hátráltathatja, melyek között Broadfoot és mtsai (1999: 5) a következőket nevezik meg:

- az a tendencia, hogy a tanárok az osztálytermi munka mennyiségét értékelik a tanulás minősége helyett;

- a tanárok nagyobb figyelmet szentelnek az osztályozásnak, ami sok esetben csorbítja a tanuló önértékelését, és nem ad kézzelfogható útmutatást a tanulónak ahhoz, hogy fejlődni tudjon;

- a tanárok nagy hangsúlyt fektetnek a tanulók egymással történő összehasonlítására, ez demoralizálja a kevésbé sikeres tanulókat; 
- a tanulók számára adott visszacsatolások gyakran más célokat szolgálnak (pl. csoportszervezési, szocializációs cél), nem pedig a hatékonyabb tanulás támogatására irányulnak;

- a tanárok nem ismerik elég jól tanulóik tanulási igényeit.

A tanulást támogató értékelés gyakorlatban történő megvalósítását többen is igyekeztek megvilágítani (Assessment Reform Group, 2002; Black és mtsai, 2004). Az Értékelési Reform Csoport arra mutatott rá, hogy azok a hétköznapi osztálytermi tevékenységek, amelyekben a tanár a tanulókkal együtt vesz részt, valamilyen formában az értékeléshez kapcsolhatóak, hiszen a tanulók által teljesített feladatok vagy a tanár kérdéseire adott válaszok alapján a tanulók ismereteiről, készségeikről képet lehet alkotni. Ez azt jelenti, hogy az értékelés lényegében átszövi az osztálytermi gyakorlat egészét. Black és mtsai (2004) konkrét technikákat is ajánlanak az önértékeléshez „közlekedési lámpák” megjelöléssel: a zöld színű pohár jelzi, hogy a saját teljesítményüket jónak vagy egy adott probléma megértését megfelelőnek értékelik. A piros szín a sikeres feladatteljesítés vagy problémamegértés hiányára utal, míg a sárga szín részleges feladatteljesítést és megértést jelöl. Az önértékelést követően a tanulók megvitathatják meglátásaikat és érveiket kis csoportban, és így a társértékelésre is lehetőség nyílik. A tanulók véleménynyilvánításához, a feladatteljesítés tanulók általi kiértékeléséhez a tanárnak lehetőséget kell biztosítani, mivel ezek a lépések a tanulási folyamat szerves részei. Az érdemjegyek vagy pontszámok mellőzése is erősen javasolt a tanulók teljesítményének értékelésekor, helyette a tanulók fejlődéséhez szükséges konkrét lépéseket, teendőket, javaslatokat kell megnevezni. Black és mtsai (2004) azt is a lehetséges osztálytermi eljárások közé sorolják, hogy a tanulók egymásnak kérdéseket írnak, vagy egymás feladatmegoldásait kiértékelik. A teszt összeállítása és az értékelési kritériumok alkalmazása egyaránt fokozhatja a tanulók értékelői tudatosságát és készségét.

Broadfoot és mtsai (1999) szerint a tanulást támogató értékelés a fentebb részletezett jellemzők alapján nem teljesen fedi le a fejlesztő értékelés fogalmát, attól részben eltér. A kettő közötti különbséget az adja, hogy a tanulást támogató értékelésnél a tanuló személyre szabott visszacsatolást kap a továbblépéshez, vagy maga is aktívan részt vesz saját vagy tanulótársai teljesítményének értékelésében. A tanulást támogató értékelés fogalmát az is megkülönbözteti a fejlesztő értékeléstöl, hogy az utóbbi irányulhat csupán csak arra, hogy a tanulók előrehaladásáról információt nyújtson a tanárnak, hogy szükséges-e a tanmeneten változtatni (Stiggins, 2002). A tanulást támogató értékelés azonban soha nem szorítkozhat csak az ellenőrző szerepre, hiszen eredeti funkcióját úgy tudja betölteni, hogy a tanulók továbbhaladásához megadja a konkrét lépéseket is.

Earl és Katz (2005) a tanulást támogató értékelés definícióját tovább árnyalta azáltal, hogy az értékelést a tanuló számára külön elsajátítandó területként azonosította. 
Az utóbbi olyan metakognitív folyamatokat foglal magába, melyeket a tanuló tanári segítséggel az értékelés végzése során aktivál. Ezen folyamatok kiteljesedése a következőkben érhető tetten:

- az önértékelés modellezése és a készség elsajátíttatása;

- segítségnyújtás a tanulási célok megfogalmazásához és azok eléréséhez;

- a tantervi célokat tükröző minőségi teljesítmény modellezése;

- a jó gyakorlat kritériumainak megvilágítása a diákokkal történő szoros együttmüködés során;

- segítségnyújtás abban, hogy a diákok kifejlesszék a belső visszajelzést adó, önszabályozó mechanizmusaikat annak érdekében, hogy ellenőrizzék vagy megkérdőjelezzék saját gondolataikat, tudják tolerálni a kétértelmüséget vagy a bizonytalanságot, amely minden új ismeret megszerzését jellemez;

- rendszeres és megfelelő kihívást adó gyakorlási lehetőségek biztosítása, hogy a diákok kompetens önértékelőkké válhassanak;

- a diákok metakognitív folyamatainak és tanulásának monitorozása, azokról leíró visszacsatolás biztosítása;

- olyan tanulási környezet biztosítása, melyben a diákok szabadon és bátran kockáztathatnak.

A fejlesztő értékelés a fenti értelmezésben előtérbe helyezi a diákot mint értékelést végző személyt. Ez a szerep a hagyományos, tanárközpontú értékeléstől idegen, hiszen ott az értékelés a tanár felelősségi körébe tartozik.

A tanulást támogató értékelésre vonatkozóan Taras (2009) fogalmazott meg kritikai észrevételt. Szerinte a fogalom értelmezése és gyakorlati megvalósítása nem elfogadható, ha a fejlesztő értékelés kiszorítja a minősítő értékelést, mivel az osztálytermi értékelés nem szorítkozhat csak a tanuló fejlesztésére. A minősítő értékelés minimalizálását, esetleges kivonását az motiválhatta, hogy a tanulást támogató értékelést az egyén tanulásán túlmutató, egyéb társadalmi jelentőséggel is felruházták. Broadfoot és Black (2004) például a társadalmi reform lehetséges eszközének tekintette a tanulást támogató értékelést, hiszen az egyéni önmegvalósítás és kreativitás felerösödhet, a közösség támogató ereje segíthet a kitüzött célok elérésében, de az egyén számára saját sorsának vagy karrierjének irányításához is megfelelő alapot nyújthat.

A minősítő értékelés és a tanulást támogató értékelés közötti kapcsolat hiányának oka az is lehetett, amire Stiggins (2007), illetve Black és Wiliam (1998) is felhívta a figyelmet: az USA-ban és Angliában az 1990-es évekre a külső, standardizált tesztekbe vetett hit az osztálytermi értékelésben úgy csapódott le, hogy a minősítö értékelés jelentőségét felnagyította, holott az a tanulás eredményességét nem az elvárt módon 
befolyásolta. A minősítő értékelés lebonyolításához azonban a tanárok lényegében csak minimális alapképzésben részesültek, azaz értékelési müveltségük (assessment literacy) meglehetősen hiányosnak volt mondható. Stiggins (2007) elismeri mind az eredményorientált, mind a tanulást támogató értékelés fontosságát, de rámutat arra az általa mítosznak nevezett téves nézetre, mely szerint az érdemjegyek és tesztpontszámok képesek növelni a tanulók motivációját és tanulási eredményességét.

A fentebb vázolt tanulást támogató potenciál és egyéb előnyök ellenére a tanulást támogató értékelés széles körü alkalmazása nem valósult meg, melynek okait Black (2010) a következő tényezőkkel hozza összefüggésbe. Számos nemzeti oktatási rendszerben meghatározó szerepet játszanak a külső, standardizált vizsgák, melyek tétje igen nagy, adott esetben tanulók sorsát pecsételhetik meg. Ilyen oktatási kontextusban a tanárok úgy ítélhetik meg, hogy a vizsgára való felkészítés, a tanítás vizsgának történő alárendelése a helyes és üdvözítő döntés. Ez értelemszerüen korlátozza az osztálytermi munka lehetséges formáinak kiválasztását. Ennek feloldásához a tanárnak rendelkeznie kellene megfelelő mérésszakmai ismeretekkel, más szóval értékelési müveltséggel, hogy döntéseit azokra alapozva, és ne külső kényszer vagy vélt társadalmi elvárások mentén hozza meg. Black szerint a tanárnak ismernie kell a minősítő, eredményorientált értékelés alapvető szakmai elvárásait (pl. a teszt érvényessége és megbízhatósága), valamint hogy azokat hogyan lehet biztosítani. Ugyanakkor a tanárnak tisztában kell lennie a fejlesztő értékelés elveivel és lehetséges technikáival is. A két értékelés szinergiája nyújtja a tanárok számára a megfelelő szakmai alapot osztálytermi értékelési feladataik megvalósításához.

A tanulást támogató értékelés áttekintése után még két fejlesztő értékelést jelölő elnevezést vizsgálunk meg röviden, melyek visszhangja lényegesen kisebb a szakirodalomban, azonban mindkettő a tanuló idegen nyelvi fejlődését meghatározó aspektusokra fókuszál. A tanulást támogató értékeléssel összevetve a dinamikus értékelés (dynamic assessment) és a tanulás-orientált értékelés (learning-oriented assessment) az értékelés osztálytermi folyamatokba való beágyazottságát sokkal kiemeltebben hangsúlyozza.

\section{A dinamikus értékelés}

A dinamikus értékelés (Lantolf és Poehner, 2008; Poehner és Lantolf, 2005) a tanár és tanuló között létrejövő szóbeli interakciót vizsgálja a Vygotsky-féle (1978) szociokulturális elmélet keretein belül, mely szerint a társas interakció döntő szerepet játszik az egyén fejlődésében, hiszen gondolkozásunkat és ismereteinket a környezetünkkel (másokkal) történő interakció segítségével konstruáljuk. Vygotsky elmélete szerint a tanuló rendelkezik egy úgynevezett legközelebbi vagy köztes távolságra lévő (proximális) fejlődési zónával (zone of proximal development), mely a tanuló tényleges fejlettségi szintje és potenciális fejlödési szintje között helyezkedik el. A kettő közötti szakadékot mediációval, azaz közvetítői segítséggel lehet áthidalni. Ez a 
feladat az osztályteremben döntően a tanárra hárul. Poehner és Lantolf (2005) kiemeli, hogy a dinamikus értékelés során az értékelés és a tanítás nem válik szét: a tanulóval folytatott interakcióba beágyazódik a tanári mediáció, melynek legfőbb célja a tanuló fejlődésének a támogatása. Ez úgy valósulhat meg, hogy a tanár diagnosztizálja (értékeli) a tanuló aktuális nyelvi problémáját és egyidejüleg kezeli is: a tanuló számára irányított kérdést tesz fel, vagy sugalmaz valamit a nyelvi probléma leküzdéséhez. Ez a jellemző különbözteti meg a dinamikus értékelést a visszacsatolástól, amelynek nem feltétele az interakcióba ágyazottság. A dinamikus értékelés a tanuló fejlődését kis lépésekben támogatja és evolúciós természetünek mondható, mivel a tanuló fejlődési folyamatában visszalépések is előfordulnak. Hosszabb távon, ahogy a tanuló egyre jobban fejlődik, illetve önszabályozó képessége megerősödik, a dinamikus értékelés szerepe csökkenhet.

A dinamikus értékelés nem egy értékelési eszköz vagy módszer, hanem egy olyan elméleti keretrendszer, melyben értelmezni lehet a tanítás és az értékelés integrált folyamatait, azon belül a tanuló fejlödését támogató tanári mediációt. A dinamikus értékelésre és a legközelebbi fejlődési zóna vizsgálatára irányuló kutatást (Davin, 2016; Lanfolf és Poehner, 2011; Poehner, 2009) nehezíti az a tény, hogy a vizsgálat tárgyát képező tanár-diák (azaz kétszereplős) interakció igen korlátozott az osztálytermi nyelvóra keretei között, hiszen a tanítás csoportban történik. A nehézségek ellenére Poehner (2009) kiemeli, a nyelvtanulás és -tanítás folyamatának megértéséhez elengedhetetlen, hogy megértsük, hogyan alakul, fejlődik a tanuló idegennyelv-tudása, és a tanulás eredménye helyett a tanulás folyamatát kell elemeznünk. A dinamikus értékelés kutatása ezen célkitüzés miatt sok közös vonást mutat a második nyelv elsajátítása területén végzett kutatásokkal, például a szóbeli korrekciós visszacsatolásra (oral corrective feedback) irányuló vizsgálatokkal. A második nyelv elsajátításával foglalkozó kutatások azt vizsgálják, hogy az implicit vagy explicit visszacsatolás hatásosabb-e a nyelvelsajátítás eredményességét tekintve (pl. Lyster és Ranta, 1997; Lyster és Saito, 2010; Nassaji, 2009).

\section{A tanulás-orientált értékelést}

A tanulás-orientált értékelés (learning-oriented assessment) megnevezést elöször Carless (2007) használta egy olyan osztálytermi értékelési formát jelölve meg vele, amelyben az értékeléshez használt feladatok is tanulási célt szolgálnak. Valójában a tanuló fejlődésének a lehetősége fontosabb, mint az értékelés maga. Továbbá a tanulók önértékelést és társértékelést végeznek, és a visszacsatolás legfontosabb funkciója az, hogy a tanulónak utat mutasson a továbblépéshez (feedforward). Az előbbi célok megvalósítása három pilléren nyugszik (Carless, 2007). Elöször is a feladat megtervezésén: az értékeléshez használt feladatot a tanulás céljának kell alárendelni. Másodsorban a tanulók értékelői kompetenciáját ön- és társértékelés keretében kell fejleszteni, hogy a kitűzött tanulási célokat jobban megértsék, az elvárt szint minőségi 
mutatóival tisztában legyenek. Harmadsorban a tanulónak jól időzített visszacsatolást kell adni, mely cselevésre készteti és ténylegesen kihat a fejlődésére, vagyis a visszacsatolást adó személy számára is jól beazonosítható az eredmény. A tanulásorientált értékelés nemcsak a fejlesztő, de a minősítő értékelést is szolgálhatja, azaz a két értékelési forma között Carless igyekszik megtalálni az egyensúlyt, nem pedig azt hangoztatja, hogy az egyik előbbre való, mint a másik. A tanulás-orientált értékelés megvalósítását Carless a felsőoktatás tágabb kontextusában vizsgálta, nyelvtanulásra irányuló kutatást nem végzett.

A tanulás-orientált értékelésnek azonban létezik egy másik értelmezése is, mely Turner és Purpura (2015) nevéhez füződik. A fogalmat ők célzottan a nyelvtanulásra vonatkoztatva vizsgálták. Szerintük az osztálytermi értékelést komplexen kell vizsgálni, és ennek megfelelően a tanulás-orientált értékelés egy olyan tanulás- és tanuló-központú megközelítés, mely arra törekszik, hogy a leghatékonyabban támogassa a tanuló nyelvi fejlődését az értékelés különböző formái alapján nyert információk segítségével, mint például tesztek, megfigyelések, megbeszélések, ön- és társértékelések, projektek, portfóliók, osztálytermi szóbeli diskurzus értékelési mozzanatai. Turner és Purpura azonban túllép a minősítő és fejlesztő értékelés, illetve a tanulás eredmény-orientált értékelése és a tanulást támogató értékelés dichotómiáján. Értelmezésük szerint a tanulás-orientált értékelés elismeri a tanítás, a tanulás és az értékelés közötti bonyolult kölcsönhatásokat, és közülük hét, a tanuló fejlődését meghatározó, úgynevezett kritikus dimenziót különböztet meg:

- a kontextus mint dimenzió (a tanulás társadalmi, kulturális vagy oktatási kontextusa),

- az előhívási dimenzió (a teljesítmény kiváltására használt módszer),

- a nyelvtudás szintje mint dimenzió (az elérni kívánt nyelvtudás szint és annak nyomon követése),

- a kognitív vagy tanulási dimenzió (a nyelvi performanciát és tanulást meghatározó szociokognitív jellemzők),

- az affektív dimenzió (a nyelvi performancia és tanulás során aktivált szemléleti és érzelmi beállítottság),

- az interakciós dimenzió (az értékelés során létrejövő kommunikáció interakciós jellemzői, pl. beszélőváltás),

- és a tanári dimenzió (az oktató tárgyi tudása, pedagógiai ismeretei és értékelési müveltsége).

Carless (2007), illetve Turner és Purpura (2015) fogalomértelmezésében az a közös vonás, hogy az osztálytermi értékelést mindkettő egységes keretben képzeli el, és elveti 
a dichotóm értékelési formák közötti választást. Továbbá Turner és Purpura az osztálytermi értékelést külső és belső, makro és mikro tényezők relációjában értelmezi, míg Carless döntően a tanulók aktív bevonását hangsúlyozza.

Az osztálytermi értékelés általunk bemutatott felfogásainak - a tanulást támogató értékelésnek, a dinamikus értékelésnek és a tanulás orientált értékelésnek - közös vonása, hogy az értékelés nem különül el a tanítástól, annak szerves részét képezi. A koncepciók közötti különbségek abban érhetők tetten, hogy mit helyeznek az értékelés fókuszába. A tanulást támogató értékelés egyrészt a tanuló fejlődését lépésekre lebontott konstruktív visszacsatolással kívánja elérni, másrészt azt tartja fontosnak, hogy a tanulók is aktívan részt vegyenek saját és társaik teljesítményének az értékelésében. Az előbbi eljárások osztálytermi alkalmazása hosszabb távon pozitívan hathat a tanulók célorientációjára, tanulási motivációjára és önszabályozó képességére. A dinamikus értékelés ezzel szemben a tanár és tanuló között létrejövő párbeszéd kontextusában a visszacsatoláson túl arra helyezi a hangsúlyt, hogy a tanár kérdező technikái milyen módon képesek a tanuló fejlődését támogatni. Értékelés lényegében itt a tanár részéről történik, akinek azt kell tudni felmérni, hogy a tanuló mire áll készen, mi tartozik a legközelebbi fejlődési zónájába, hiszen a tanuló fejlődését csak célzott és megfelelő szintű (nyelvi) támogatás képes elősegíteni. A tanulás-orientált értékelés Turner és Purpura (2015) nevéhez köthető értelmezése pedig a legtágabb kontextusban vizsgálja az osztálytermi értékelést, hiszen külső és belső tényezők meghatározó szerepét egyidejűleg igyekszik feltárni.

\section{A magyarországi (részleges) helyzetkép}

Az osztálytermi értékelés magyarországi empirikus vizsgálatai közül két tanulmányt szeretnénk kiemelni: egyrészt szeretnénk egy példával illusztrálni a tanulást támogató értékelés sikeres gyakorlati megvalósítását, másrészt rá kívánunk világítani a tanári visszacsatolás angolórákon leggyakrabban alkalmazott formáira. A reformpedagógiai kísérlet azt bizonyítja, hogy a tanulóközpontú osztálytermi értékelés a sikeres tanulás katalizátorává válhat. A leggyakoribb tanári visszacsatolási formák alapján kibontakozó helyzetkép pedig a szemléletváltás szükségességét támasztja alá.

A reformpedagógiai kezdeményezés - Lépésröl lépésre (Step by Step) eredményességét Becze (2012) vizsgálta. A 90-es években indult program fenntartható módon kívánta biztosítani a hátrányos helyzetből induló, kudarcokat elszenvedett tanulók felzárkóztatását. Az Észak-Alföld régió 64 közoktatási intézményében végzett vizsgálat megerősítette, hogy a program során bevezetett módszertani megújulás innovatív értékelési eljárások alkalmazásával párosult. Ez azt jelentette, hogy a hagyományos osztályozási formával szemben az egyéni különbségeket figyelembe vevő, tanulókhoz igazított, fejlődést segítő értékelési eljárásokat helyezték előtérbe az órákon. Az osztálytermi értékelés során a tanulót önmagához viszonyító visszacsatolás, a saját fejlődési folyamatára reflektáló visszajelzés játszotta a legnagyobb szerepet. A 
programban mindenki értékelt, aki részese volt a tanulásnak, így a tanulók saját és társaik munkáját, elért eredményeiket egyaránt értékelték. A tanulást támogató értékelés gyakorlati megvalósítása sikeresnek bizonyult a Lépésről lépésre reformpedagógiai kezdeményezés eredményeképpen.

A helyzetfeltáró céllal készült másik tanulmány azt világítja meg, hogy mi jellemzi az osztálytermi gyakorlatot a nyelvtudásmérésre és az értékelésre vonatkozóan több európai ország viszonylatában, köztük Magyarországon (Csépes, 2019). A kutatás a „Teachers' Assessment Literacy Enhancement” (TALE) [Tanárok nyelvtudásmérési müveltségének a fejlesztése] elnevezésű projekt keretében valósult meg, melyben 230 magyarországi angoltanár és tanárjelölt vett részt. A 2016-ban végzett kérdőíves felmérés külön kitért az osztálytermi visszajelzési/visszacsatolási formák vizsgálatára. A kapott eredmények alapján az a tendencia figyelhető meg, hogy a válaszadó tanárok döntően érdemjegyet és rövid szöveges megjegyzést használnak az angolórákon (93\% és 59,3\%). A tanulást támogató, fejlesztő célú visszacsatolási formák - a részletes értékelés vagy a diáknak szánt egyéni útmutatás - lényegesen kevésbé használt formák minden vizsgált országban, de különösen Magyarországon alacsony ezen eljárások gyakorisága (23,6\% és 56,6\%). A szerző szerint a jelenség magyarázatául az szolgálhat, hogy a válaszadók nem részesültek megfelelö képzésben, hogy a részletes visszajelzést kezelni tudják, valamint nincs kellő rálátásuk az adott visszacsatolási formák tanulást támogat szerepére.

\section{Konklúzió}

Az eredményes (nyelv)tanulás az oktatás minden szereplőjének érdeke. Tanulmányunkban arra mutattunk rá, hogy az osztálytermi értékelés hogyan támogathatja az eredményes tanulást a fejlesztő értékelés segítségével. A fejlesztő értékelés különböző elméleti megközelítéseit - a tanulást támogató értékelést, a dinamikus értékelést és a tanulás-orientált értékelést - azért vetettük össze, hogy felhívjuk a figyelmet az osztálytermi értékelés eltérő értelmezéseire és a megvalósítás lehetséges formáira. A tanulmányunkban bemutatott értékelési megközelítések támpontot nyújthatnak a tanárok számára jelenlegi értékelési szemléletük átgondolásához és megváltoztatásához, több teret biztosítva a fejlesztő értékelésnek. A változtatás szükségességét a TALE projekt kutatási eredményei is alátámasztják (Csépes, 2019). Hogy a magyar közoktatás színterein egyensúlyba tud-e kerülni a tanulás eredmény-orientált értékelése és a tanulást támogató értékelés, feltehetően számos kontextuális tényező befolyásától függ, mint például a társadalmi elvárások, vagy a helyi oktatási környezet (iskola) sajátosságai. Ezen változók vizsgálata különösen indokolt lenne a bevezetöben vázolt nyelvtanulási sikertelenség miatt. Earl (2006) szerint egy új pedagógiai szemlélet elfogadása eleve kihívást jelent a tanároknak, hiszen sokszor megszokott, régi beidegződéseket kell feladniuk új eljárások bevezetése miatt. Az osztálytermi értékelés főszereplőinek - a tanulóknak - azonban az az érdeke, 
hogy minél eredményesebbek legyenek, és senki se érezze magát vesztesnek. Az adott cél elérésében a tanárra igen fontos szerep hárul: neki kell 'ablakot nyitni a legsötétebb helyzetben' is, utat mutatni a diákok számára a továbbfejlődéshez. A tanulás eredményorientált értékelése mellett ezért elengedhetetlen, hogy a tanár mindenkit egyéni képességeihez mérten is értékeljen és támogasson, mivel a tanulók önszabályozó képessége ezáltal teljesedhet ki.

\section{English title and abstract}

\section{How to promote (language) learning through formative assessment?}

The paper is intended to provide a review of formative assessment with a special focus on language learning. We examine how the concept has evolved over the past 30 years and why it appears to receive increasing attention nowadays. In our view, assessment should be seen as an integral part of the language classroom. It can considerably impact on learners' motivation and self-confidence, which in turn may boost student achievement. The review highlights three approaches to formative assessment: assessment for learning, dynamic assessment and learning-oriented assessment. These differ in certain respects but all of them view teaching, learning and assessment as interconnected and inseparable. The paper also gives a brief outlook on research on formative assessment in the Hungarian context. According to some findings on classroom-based assessment in English lessons, there is a need for change in teachers' perceptions with regard to formative assessment.

Keywords: classroom-based assessment, formative assessment, assessment for learning, differentiated assessment, language assessment literacy

\section{Irodalom}

Assessment Reform Group. 2002. Assessment for learning: 10 principles. https://www.aaia.org.uk/news/article/assessment-for-learning-10-principles (Letöltés: 2020.12.11.)

Becze, Orsolya. (2012). A külső vezérlésü innovációs kezdeményezések szerepe a közoktatás reformjában. Új pedagógiai szemle, 62(9-10), 92-134. https://epa.oszk.hu/00000/00035/00154/pdf/EPA00035_upsz_2012_09-10_092134.pdf (Letöltés: 2021.02.23.)

Bennett, Randy Elliot. 2011. Formative assessment: a critical review. Assessment in Education: Principles, Policy \& Practice, 18(1): 5-25. https://doi.org/10.1080/0969594x.2010.513678 
Birenbaum, Menucha. 1996. Assessment 2000: Towards a Pluralistic Approach to Assessment. In: Menucha Birenbaum és Filip Dochy (szerk.) Alternatives in Assessment of Achievements, Learning Processes and Prior Knowledge. Boston: Kluwer. 3-29.

Black, Paul. 2010. Formative Assessment. In: Penelope Peterson, Eva Baker és Barry McGaw (szerk.) International Encyclopedia of Education, 3rd ed. Oxford: Academic Press. 359-364. https://kclpure.kcl.ac.uk/portal/en/publications/formative-assessment(25c8ab73e935-472d-8d5c-679ec2d9740f)/export.html (Letöltés: 2020.10.06.)

Black, Paul és Dylan Wiliam. 1998. Inside the black box: Raising standards through classroom assessment, Phi Delta Kappan International. http://edci770.pbworks.com/w/file/fetch/48124468/BlackWiliam_1998.pdf (Letöltés: 2020.12.27)

Black, Paul, Christine Harrison, Clare Lee, Bethan Marshall, és Dylan Wiliam. 2004. Working Inside the Black Box: Assessment for Learning in the Classroom. Phi Delta Kappan, 86(1): 8-21. https://doi.org/10.1177/003172170408600105

Bognár, Mária. 2006. A fejlesztő értékelés osztálytermi gyakorlata. Új pedagógiai szemle, 56(3): 19-26. http://epa.oszk.hu/00000/00035/00101/2006-03-ko-BognarFejleszto.html (Letöltés: 2020.01.30.)

Brassói, Sándor, Hunya Márta és Vass Vilmos. 2005. A fejlesztő értékelés: az iskolai tanulás minőségének javítása. Új pedagógiai szemle, 55(7-8): 4-17. https://epa.oszk.hu/00000/00035/00094/2005-07-ta-Tobbek-Fejleszto.html (Letöltés: 2020.02.10.)

Broadfoot, Patricia és Paul Black. 2004. Redefining assessment? The first ten years of Assessment in Education. Assessment in Education: Principles, Policy \& Practice, 11(1): 7-26. https://doi.org/10.1080/0969594042000208976

Broadfoot, Patricia, Richard Daugherty, John Gardner, Caroline Gipps, Wynne Harlen, Mary James és Gordon Stobart. 1999. Assessment for Learning: Beyond the Black Box. Nuffield Foundation and University of Cambridge. http://www.nuffieldfoundation.org/sites/default/files/files/beyond_blackbox.pdf (Letöltés: 2020.09.15)

Carless, David. 2007. Learning-oriented assessment: conceptual bases and practical implications. Innovations in Education and Teaching International, 44(1): 57-66. https://doi.org/10.1080/14703290601081332

Csépes, Ildikó. 2019. Hogyan fejleszthető a tanárok nyelvtudásmérési és értékelési műveltsége? Az Erasmus+ TALE projekt. Modern Nyelvoktatás, 25(3-4): 136155. 
Davin, Kristin J. 2016. Classroom Dynamic Assessment: A Critical Examination of Constructs and Practices. The Modern Language Journal, 100(4): 813-829. https://doi.org/10.1111/modl.12352

Earl, Lorna M. és Steven Katz. 2005. Rethinking classroom assessment with purpose in mind. Winnipeg, Manitoba: Western Northern Canadian Protocol. https://digitalcollection.gov.mb.ca/awweb/pdfopener?smd=1\&did=12503\&md=1 (Letöltés: 2020.11.30)

Einhorn, Ágnes. 2015. Pedagógiai kultúraváltás az idegennyelv-tanításban? Vitaindító. Modern Nyelvoktatás, 21(4): 48-58.

Europeans and their Languages. 2006. European Commission. https://ec.europa.eu/commfrontoffice/publicopinion/archives/ebs/ebs_243_en.pdf (Letöltés: 2020. 10. 28.)

Europeans and their Languages. Report. 2012. Special Eurobarometer 386. European Commission. http://ec.europa.eu/public_opinion/archives/ebs/ebs_386_en.pdf (Letöltés: 2020. 10. 28.)

Gipps, Caroline. 1994. Beyond testing: Towards a theory of educational assessment. London: Falmer Press.

Golnhofer, Erzsébet. 2001. Új értékelési kultúra kibontakozása. Iskolakultúra, 11(9): 78-82. http://real.mtak.hu/61024/1/EPA00011_iskolakultura_2001_09_078082.pdf (Letöltés: 2020.05.10.)

Green, Anthony. 2014. Exploring Language Assessment and Testing. Oxon: Routledge.

Harlen, Wynne. 2005. Teachers' summative practices and assessment for learning tensions and synergies. Curriculum Journal, 16(2): 207-223. https://doi.org/10.1080/09585170500136093

Inbar-Lourie, Ofra. 2008. Language Assessment Culture. In: Elena Shohamy and Nancy H. Hornberger (szerk.) Encyclopedia of Language and Education, 2nd ed., Volume 7: Language Testing and Assessment. New York: Springer Science+Business Media. 285-299.

Katona, Nóra, Konrád Ágnes, Perlusz Andrea, Polányi Viktória, Porogi András és Sisa Péterné. 2020. A tanulás és tanítás súlypontjai. Eger: Eszterházy Károly Egyetem. https://www.oktatas2030.hu/wp-content/uploads/2020/10/a-tanulas-s-tanitassulypontjai.pdf (Letöltés: 2021.02.23.)

Lantolf, James P. és Matthew E. Poehner. 2008. Dynamic Assessment. In: Elena Shohamy and Nancy H. Hornberger (szerk.) Encyclopedia of Language and Education, 2nd ed., Volume 7: Language Testing and Assessment. New York: Springer Science+Business Media. 273-284. 
Lantolf, James P. és Matthew E. Poehner. 2011. Dynamic assessment in the classroom: Vygotskian praxis for second language development. Language Teaching Research, 15(1): 11-33. https://doi.org/10.1177/1362168810383328

Lyster, Roy és Leila Ranta. 1997. Corrective feedback and learner uptake. Studies in Second Language Acquisition, 19, 37-66. https://doi.org/10.1017/s0272263197001034

Lyster, Roy és Kazuya Saito. 2010. Oral feedback in classroom SLA. Studies in Second Language Acquisition, 32(2), 265-302. https://doi.org/10.1017/s0272263109990520

Lau, Alice Man Sze. 2016. 'Formative good, summative bad?' - A review of the dichotomy in assessment literature. Journal of Further and Higher Education, 40(4): 509-525. https://doi.org/10.1080/0309877x.2014.984600

Nassaji, Hossein. 2009. Effects of recasts and elicitations in dyadic interaction and the role of feedback explicitness. Language Learning, 59(2), 411-452. https://doi.org/10.1111/j.1467-9922.2009.00511.x

Poehner, Matthew E. 2009. Group Dynamic Assessment: Mediation for the L2 Classroom. TESOL Quarterly, 43(3): 471-491. https://doi.org/10.1002/j.15457249.2009.tb00245.x

Poehner, Matthew E. és James P. Lantolf. 2005. Dynamic assessment in the language classroom. Language Teaching Research 9(3): 233-265. https://doi.org/10.1191/13621688051r166oa

Purpura, James E. 2016. Second and Foreign Language Assessment. The Modern Language Journal, 100(S1): 190-208. https://doi.org/10.1111/modl.12308

Rea-Dickins, Pauline és Sheena Gardner. 2000. Snares and silver bullets: disentangling the construct of formative assessment. Language Testing, 17(2): 215-243. https://doi.org/10.1177/026553220101800407

Sadler, D. Royce. 1998. Formative assessment: Revisiting the territory. Assessment in Education, 5(1): 77-84. https://doi.org/10.1080/0969595980050104

Scriven, Michael. 1967. The Methodology of Evaluation. In: Ralph W. Tyler, Robert M. Gagné és Michael Scriven (szerk.) Perspectives of Curriculum Evaluation. AERA Monograph Series on Curriculum Evaluation, 1. Chicago: Rand McNally. 39-83.

Stiggins, Richard J. 2002. Assessment Crisis: The Absence of Assessment for Learning. Phi Delta Kappan, 83(10): 758-765. https://doi.org/10.1177/003172170208301010 
Stiggins, Richard J. 2007. Five Assessment Myths and Their Consequences. Education Week, 27(8): 28-29. https://www.edweek.org/teaching-learning/opinion-fiveassessment-myths-and-their-consequences/2007/10 (Letöltés: 2020.11.23.)

Taras, Maddalena. 2009. Summative assessment: the missing link for formative assessment. Journal of Further and Higher Education, 33(1): 57-69. https://doi.org/10.1080/03098770802638671

Turner, Carolyn E. és James E. Purpura. 2015. Learning-oriented assessment in second and foreign language classrooms. In: Dina Tsagari \& Jayante Banerjee (szerk.), Handbook of second language assessment. Boston: De Gruyter Mouton. 255-272.

Vygotsky, Lev S. 1978. Mind in society: The development of higher psychological processes. Cambridge, MA: Harvard University Press. 